\title{
The Influence of Feminist Philosophy on Nursing Practice
}

\author{
Carolyn M. Sampselle
}

This paper describes how feminist beliefs and values should influence nursing practice. Traditionally held patriarchal values are challenged, and the feminist tenets of gender equity, the basis for value to society and personal sovereignty are discussed. Drawing on experience as a nurse practitioner this writer gives examples of nursing practice that are grounded in feminist philosophy.

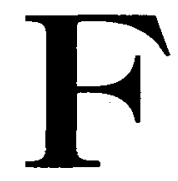

eminist philosophy challenges gender-biased social practices and questions the beliefs and values from which such practices arise. Sexism, like racism, is not fashionable in contemporary society, and among today's nurses disagreement with the principles of feminist philosophy is rare. For example, nurses clearly support equal pay for comparable work and would be unlikely to suggest that women are less competent than men.

On the other hand, nurses are products of a patriarchal culture that historically has viewed men as physically and intellectually superior to women. Traditional values, often deeply entrenched and rarely questioned, may cause behaviors that perpetuate the negative attitudes women continue to encounter. Concern about the impact of values was expressed by the President's Commission on Mental Health (1978):

The rapidly changing role of women has left many traditionally trained mental health practitioners ill-prepared to deal with the new problems that women face as a result... We are concerned by the failure of mental health practitioners to recognize, understand, and empathize with the feelings of powerlessness, alienation, and frustration expressed by many women (p. 7).

Nurses are mandated by various professional standards (American Nurses Association, 1973; Nurses Association of the American Council of Obstetricians/Gynecologists, 1986) to protect the rights of their clients, rights that most nurses would acknowledge encompass the basic rights expressed in feminist philosophy. Do nurses believe this? If so, then nursing practice should be congruent with the tenets of feminist belief. However, nurses who have been socialized in a patriarchal society many not recognize incongruities in their practice.

The purpose of this paper is to consider how feminist beliefs and values should influence nursing practice. The basic tenets of feminist philosophy are outlined, and traditionally held patriarchal values are challenged. Drawing on experience as a nurse practitioner, this writer gives examples of nursing practice that are grounded in feminist philosophy.

\section{An Overview of the Tenets of Feminism}

Feminist philosophers have pointed out that traditional Western society has been shaped by the male-dominated majority culture (Belenky, Clinchy, Goldberger \& Tarule, 1986). A foundational value of this majority has been the belief that the characteristics and behaviors of males constitute the norm, while those of females are believed to be abnormal or deviant (Bardwick, 1980). The result of this traditional belief system has been the difficulty most women have in establishing their authority (Hall \& Sandler, 1982; West \& Zimmerman, 1983), achieving recognition and reward in the work arena (Becker \& Able, 1978; Kragen, 1987) and receiving sufficient information to make informed judgments about health care (Bernstein \& Kane, 1981; Scully, 1982).

As various feminist writers (de Beauvoir, 1974; Gilligan, 1982; MacKinnon, 1989) have attempted to redress the unfair attitudes encountered by women, basic tenets of

Carolyn M. Sampselle, R.N.,C.,Ph.D, O.G.N.P., Rho, is Assistant Professor of Parent-Child Nursing, University of Michigan.

Correspondence to school of Nursing. University of Michigan, 400

N. Ingalls, Ann Arbor, MI 48109-0482. Accepted for publication February 23, 1990. 
feminist philosophy have emerged. One important concept is the affirmation of gender equity, which advocates a partnership rather than a dominance model for human interaction. Further, feminists assert that value to society must be determined not by gender but by an individual's capacity to contribute; this questions the patriarchal view that women's primary contribution is through their sexual and reproductive functions and challenges the restricted traditional ideal of feminine beauty. A third tenet of feminism recognizes that women should be accorded the same sovereignty over their bodies as men.

\section{Gender Equity}

The patriarchal view of woman as a subspecies of man shows readily in the contemporary experience. Common language is rife with examples such as the generic use of man and masculine pronouns to represent all human beings (e.g., the paradigm that depicts nursing expertise in the areas of Man, Health and Environment); the lack of gender fairness (e.g., man and woman are parallel terms, whereas man and wife defines the man as an individual and the woman only in relationship to him) and the negative connotation reserved for words that depict feminine traits (e.g., buddy vs. sissy or master vs. mistress) (Maggio, 1987). While it has been argued that sexist or exclusive language merely reflects sex-role stereotypes, there is strong evidence that such language plays an active role in reinforcing and perpetuating gender bias (Hellinger, 1984). The Western image of God as a male figure and the depiction of the creation of woman from the rib of a man also make powerful statements about male supremacy (LaChat, 1988). If God, the Supreme Being, and Adam, the first human, embody masculine traits, then feminine traits, by default, are less esteemed.

The traditional belief that women are less capable than men has corroborated the view that women best serve society in a supporting role. Consequently, a woman's highest calling has been identified as the nurture and support of a man so he can accomplish activities that benefit society. An outcome of this view is the societal expectation that women will carry the primary responsibility for family well-being. This gender-biased expectation of woman as care provider is demonstrated in the unequal responsibility mothers think they have for their children's success and well-being (Caplan \& Hall-McCorquodale, 1985), in the unequal division of household and child-care labor that persists despite women's outside employment (Berk, 1985), and in the unequal demands placed on male and female children of elderly parents (Horowitz, 1985). Given the changing economy, with larger numbers of women working outside the home, women are placed at disproportionate risk for stress as a result of multiple role demands (McBride, 1988).

Feminist philosophers challenge the view of male supremacy. In her review of biological and cultural influences on gender-roles, Parsons (1980) concluded that the few biological differences between the sexes were not sufficient to limit women to this narrow supportive role; rather, based on cross-cultural evidence, gender-role malleability and diversity is the norm. Taking an anthropological perspective, Eisler (1988) advocated a partnership model for human interaction. In such a model diversity is honored and sought after rather than equated with either inferiority or superiority. Feminists have also challenged patriarchal theology, pointing out the less known version of creation in which both man and woman were created simultaneously in the image of God (Genesis 1:28) and the assertion of Paul in the New Testament that in Christ is neither male nor female (Galations 3:28-29) (LaChat, 1988). The movement within contemporary churches for incorporation of inclusive (nonsexist) language is a direct effort to enfranchise women as beings who reflect Godly characteristics.

Nursing practice that operationalizes the feminist point of view must use inclusive language. The written and verbal messages conveyed by the powerful symbol of language can influence the attitudes of women, indeed of society. For example, the practice of referring to women clients by their first names or as "Honey" or "Dear" while the nurse expects a more formal title demonstrates a diminished view of women. Greater sensitivity to language usage not only increases clarity of thought and accuracy of communication but also influences the attitudes of both the sender and receiver to issues of justice (Diers, 1989). Thus it is important for nurses to recognize exclusive or sexist language in client interactions and agency policies. Two excellent readings that can increase sensitivity to the use of inclusive language are Language, Gender and Professional Writing (Frank \& Treichler, 1989) and Language, Gender, and Society (Thorne, Kramarae \& Henley, 1983).

Nursing practice that reflects feminist philosophy must also acknowledge the reality of the additional strain imposed by the demands of multiple roles-strain that is often compounded by inequitable salary and differing workplace expectations. An unfortunate by-product of opening up outside employment to women has been an implicit message that they should be able to handle the added claims deriving from job and family. The nurse can demonstrate concretely the value placed on the woman's lived experiences by eliciting carefully and considering thoughtfully the woman's appraisal of the nature as well as the basis for her health problem including potential stressors related to role strain (McBride \& McBride, 1982). In my practice I aim to counteract the Supermom Myth by initiating a discussion of role overload and the strain this imposes: "It's often difficult for women to juggle work and family demands. How is it for you?"

In my work with antepartal families one goal is to lay the groundwork for a more equitable distribution of labor by meeting with the couple to explore anticipated changes: "How much additional work do you think child care will entail? How can the extra tasks be divided in a way that you both feel is fair?" The couple is encouraged to attend infant care classes so that each develops a basic skill level. Followup postpartum visits include an evaluation of each parent's satisfaction with the division of labor.

The same process applies to assisting families who are making decisions about the care of older relatives. Rather than assume the women will provide for the care of the frail elderly, the family could be challenged to derive an equitable distribution of responsibilities. Resources can be provided so that clients of both genders can develop the necessary skills to provide care, and the nurse can continue to monitor client adaptation.

\section{Basis for Value to Society}

Traditional society primarily has valued woman for her reproductive capacity and her potential as a sex object. Images that reflect these values are vividly portrayed in 
advertisements that use a very limited standard of beauty strongly influenced by male definitions of desirable sexual characteristics (Lazarus, 1987). Young, thin, airbrushed models establish an unrealistic (often unhealthy) definition of attractiveness. This idealized image of what constitutes feminine beauty has so pervaded social attitudes that obesity is viewed as evidence of a character flaw (Bennett \& Gurin, 1982) and the sexuality of older women is considered taboo (Renshaw, 1983).

Many women's health problems can be attributed at least in part to self-concept conflicts arising from the disparity between societal definitions of beauty and the physical reality of self. These conflicts are reflected in the growing incidence of eating disorders and unhealthy dieting seen in contemporary adolescents (Mallick, 1981) and the obsession with dieting seen in women of all ages (Chernin, 1981). Even during pregnancy, when maternal weight gain is essential for optimum fetal development, more that 40 percent of women reported reluctance to gain (Palmer, Jennings \& Massey, 1985). For women, concerns about body size may be compounded by being older in a society that deems women old and nonproductive at an earlier age than it deems men (Sontag, 1972).

Feminist philosophy challenges the notion that women contribute to society primarily through sexual and reproductive functions. Socialization practices are recognized as placing far greater constraints on women than on those that are imposed by biological endowment (Block, 1982). As the routes for women's productivity have expanded, feminists have also challenged limited ideals of feminine beauty. The advertising and entertainment media have been prodded to broaden the models presented for public consumption (Boston Women's Health Collective, 1984). Progress can be found in the growing numbers of women in the media who are not young, not thin, not white. Moreover, feminist writers have pointed out the contradictory messages society has been sending women that may contribute to lack of fitness. Specifically, women are encouraged to become interested and strive for expertise in food preparation that frequently leads to overeating; at the same time they are discouraged from developing athletic pursuits that would increase caloric output (McBride \& McBride, 1982).

Nurses, with their heritage of concern for the individual and placing an emphasis on health, are in an ideal position to incorporate a feminist perspective into their practice. The nurse who truly values and accepts the individual will strive to focus on unique rather than stereotypical characteristics. To identify continuing gender-bias, these nurses will examine their belief and value systems. In a nursing practice grounded in feminist principles, narrow definitions of beauty are challenged and the attractiveness of the vibrancy and energy that comes with good health at any age is affirmed. For example, with respect to the health hazards of overweight, nurses should consider whether their own attitudes are biased by the standards set forth by the media. Too often there is a knee jerk response to excess pounds in which major emphasis is placed on weight loss as the keystone to improved health. In reality, a woman is more likely to incorporate healthy life-style changes when existing selfcare is praised (e.g., if she is a nonsmoker or exercises daily) as opposed to the blame that is implied by admonitions to lose weight. In my practice, during the review of an initial physical examination of a young woman whose weight was 32 percent above recommended levels, I commented that her strong pulse rate of $68 /$ minute suggested that she had been exercising regularly. The woman responded, "I'm so glad it shows! I've been taking an hour walk five times a week. You're the first one who hasn't started in on my weight right away." The probability that this woman will continue her exercise program was undoubtedly strengthened by recognizing this positive aspect of her physical condition. The point is not to suggest excess weight should not be addressed as a health problem but that some balance be introduced into the appraisal.

With older women, besides challenging traditional stereotypes of beauty, the nurse can call into question the myths of menopause. For example, many women fear menopause because they are unduly influenced by the biomedical model of menopause as an estrogen deficiency disease (Voda \& George, 1986). This model traces its roots to a traditional patriarchal definition of menopause as crisis. Feminist scholarship has challenged this bias and redefined menopause as a normal physiologic event (Capra, 1982; Woods, 1982). Providing women with a realistic risk appraisal and accurate information about the changes their bodies are undergoing can allay much anxiety. Anticipatory guidance and on-going counsel helpwomen to view menopause as a time of expanded opportunity.

\section{Personal Sovereignty}

Until recently women have legally been the property of men rather than having sovereignty over their bodies. The de facto acceptance of violence against women, a pervasive problem in our society, is an outcome of this attitude. Wife beating accounts for 76 percent of all family violence (Ghent, DaSylva \& Farren, 1985), and it is estimated that 44 percent of American women have been victims of attempted or completed sexual assault/rape (Russel, 1984).

Violence against women is perpetrated by men of all races, ages, socioeconomic classes and occupations (Gayford, 1975; Horning, McCullough \& Sugimoto, 1981). The extent of the underlying chauvinist attitudes is demonstrated in the high proportion $(42 \%)$ of women working for the federal government who reported sexual harassment over a twoyear period (Merit Systems Protection Board, 1981) as well as in the perceptions of women that men assume intimacy and feel entitled to intrude on a woman at any time (Kelly, 1987). Such an attitude of entitlement is reflected in a survey of college-aged men, $51 \%$ of whom reported they would rape a woman if they knew they wouldn't be punished; they further thought the victim would enjoy it (Malamuth, 1981).

The problem of violence has been attributed to the individual characteristics of the perpetrator and the target. That is, some character defect or developmental deficit was used to explain the violent behavior of the inflictor as well as the "invitation" extended by the recipient. More recently, feminist literature has identified a system-based cause: violence against women is viewed as the natural result of a sexist social order (Chapman \& Gates, 1978). Collectively, men are seen to use violence against women as a means to maintain power over them. The question is not so much whether a particular man does or does not use violence but rather that so many feel entitled to express anger or frustration in this manner. The attitudes of a sexist social order operate to maintain tacit condoning of violence against women. They also support the tendency to blame the victim, which 
is seen in society and, perhaps most destructively, in the health care and legal systems (Cartwright, 1987).

Nursing has become increasingly active in addressing the issue of violence against women (Campbell \& Humphreys, 1984, Sampselle, in press). In practice, the nurse can convey the basic attitude that the woman owns her body. One powerful way to demonstrate this belief is to involve the woman actively in the pelvic examination, a procedure formerly conducted in a furtive manner with the examiner hidden from the client by a large drape. When positioned with her head elevated, and the drape (if used at all) adjusted so that face-to-face communication can occur, the woman can, if she chooses, become an active participant in the experience. Some clinicians advocate providing the woman with a hand mirror so that she can observe her own body, but I have found that positioning the mirror is an action that many women are not prepared initially to take. A wall-mounted mirror can make the view of the examination readily available to a woman whenever she chooses to look. The examiner can say, "I'll adjust this mirror so you can watch what I'm doing, if you'd like."These measures increase the woman's opportunity to gain greater knowledge and appreciation of her body. They also contribute to an atmosphere that promotes questions and discussion.

This sort of atmosphere can set the stage for further communication about related issues such as who should bear responsibility for acts of violence aimed at a woman. Often the insight that violence is the result of the misuse of power by men rather than triggered by a woman's behavior empowers abused women to leave violent relationships (Boston Women's Health Collective, 1984).

When a woman is clear about ownership of her body, the answers to other questions follow. For example, one outcome is the recognition that she should be a free and willing participant in any sexual behavior. In reality, while the sexual revolution has enabled women to be less restricted about sex, it has also implied that they ought to be readily available. Ownership of one's body means the decision to have sex is freely made, not owed to a date because he has paid for dinner and a show. With ownership also comes the right to protect one's property (i.e., a woman has the right to protect herself against sexually transmitted disease and pregnancy). One technique I have used is to role play with a woman so she is better prepared when a sensitive situation arises. For example, a man may resist the use of a condom by claiming that the sensations are not as good for him when the condom is used. The woman can be encouraged to respond that the quality of her experience is seriously impaired by worry about STD or pregnancy.

\section{Summary}

The immediate goal of the feminist movement is to address gender-based inequities in society. Because nurses often provide care to women at critical developmental points, it is important that the practice of nursing reflect the principles of feminism. By challenging traditional attitudes and values, nurses can have a beneficial effect on women's selfconcept and sense of self-ownership. Incorporating feminist philosophy into practice can make it more likely for women to become full partners in sexual, social and economic relationships and to be valued for a wide range of contributions to society. Such outcomes should enrich relationships for men as well as women because in them resides the basis for true intimacy.

Research is needed to determine how widely held are nurse's beliefs about feminist philosophy and how their beliefs are operationalized across the spectrum of specialty practice. Also, study is needed to test whether nursing practice grounded in feminist principles does, in fact, lead to better health care outcomes.

\section{References}

American Nurses Association (1973). Standards for maternal-child health nursing practice. Kansas City, Mo: The Association.

Bardwick, J. (1980). Women in transition: How feminism, sexual liberation, and the search for self-fulfillment have altered our lives. London: Harvester Press.

Becker, J., \& Able, G. (1978). Men and the victimization of women. In J. Chapmen \& M. Gates (Eds.), The victimization of women (pp. 29-52). Beverly Hills: Sage.

Belenky, M., Clinchy, B., Goldberger, N., \& Tarule, J. (1986). Women's ways of knowing: The development of self, voice, and mind. New York: Basic Books, Inc. Bennett, W., \& Gurin, J. (1982). The dieter's dilemma: Eating less and weighing more. New York: Basic Books, Inc.

Berk, S. (1985). The gender factory: The apportionment of work in American households. New York: Plenum.

Bernstien, B., \& Kane, R. (1981). Physicians' attitudes toward female patients. Medical Care, 19(6), 600-608.

Block, J. H. (1982) . Psychological development of female children and adolescents. In P. Berman \& E. Ramey (Eds.), Women: A Developmental perspective, (pp. 107 124). USHHS, NIH Publication No.82-2298.

Boston Women's Health collective (1984). The new our bodies, ourselves. New York: Simon \& Schuster, Inc.

Campbell, J., \& Humphreys, J. (1984). Nursing care of victims of family violence. Reston, VA: Reston Publishing

Caplan, P., \& Hall-McCorquodale, I. (1985). The scapegoating of mothers: A call for change. American Journal of Orthopsychiatry, 55, 610-613.

Capra, F. (1982). The turning point. Toronto: Bantam Books.

Cartwright, P. (1987). Factors that correlate with injury sustained by survivors of sexual assault. Obstetrics and Gynecology, 70(2), 44-46.

Chapmen, J., \& Gates, M. (1978). The victimization of woman. Beverly Hills: Sage.

Chernin, K (1981). The obsession: Reflecting on the tyranny of slenderness. New York Harper \& Row.

deBeauvoir, S. (1974). The second sex. New York: Vintage.

Diers, D. (1989). On modern language. . Image: Journal of Nursing Scholarship, $21(3), 122$.

Eisler, R. (1988). Partnership not dominance: A model for the human race. The World, 7-9, $60-64$.

Frank, F., \& Treichler, P. (1989) . Language, gender, and professional writing. New York: The Modern Language Association of America.

Gayford, J. (1975). Wife battering: A preliminary survey of 100 cases. British Medical Journal, 1, 194-197.

Ghent, W., DaSylva, N., \& Farren, M. (1985). Family violence: Guidelines for recognition and management. Canadian Medical Association Journal, 132(5), 541-553.

Gilligan, C. (1982). In a different voice: Psychological theory and women's development. Cambridge, MA: Harvard University Press.

Hall, R., \& Sandler, B. (1982). The classroom climate: A chilly one for women? Washington, D.C.: Association of American Colleges, Project of the Status and Education of Women.

Hellinger, M. (1984). Effecting social change through group action: Feminine occupational titles in transition. In C. Kramarae (Ed.), Language and Power. Beverly Hills: Sage.

Horning, C., McCullough, C., \& Sugimoto, T. (1981). Status relationship in marriage: Risk factors in spouse abuse. Journal of Marriage and the Family, 43, 675-692.

Horowitz, A. (1985). Sons and daughters as caregivers to older parents: Differences in role performances. The Gerontologist, 25, 612

Kagan, J. (1987). Cracks in the glass ceiling: How woman really are fairing in corporate America. Review of Business, 8(4), 10-12.

Kelly, L. (1987). Sexual violence as a continuum. Aegis, 42, 30-39.

LaChat, M. (1988). Religion's support for the domination of women: Breaking the cycle. Nurse Practitioner, 13(1), 31-34.

Lazarus, M. (1987). Still killing us softly: Advertising's image of women. Cambridge Documentary Films.

Mackinnon, C. (1989). Toward a feminist theory of the state. Cambridge, MA: Harvard University Press.

Maggio, R. (1987). The nonsexist word finder. New York: Oryx Press.

Malamuth, N. (1981). Rape proclivity among men. Journal of Social Issues, 37 (4) , 138 155. 
Mallick, M. (1981). The adverse effects of weight control in teenage girls. Advances in Nursing Science, 3(2), 121-123.

McBride, A. (1988). Mental health effects of women's multiple roles. Image: Journal of Nursing Scholarship, 20(1), 41-47.

McBride, A., \& McBride, W. (1982). Theoretical underpinnings for women's health. Women \& Health, 6, 37-55

Merit Systems Protection Board (1981). Sexual harassment in the Federal Workplace: Is it a problem? Washington, DC: U.S. Govemment Printing Office.

Nurses' Association of the American Council of Obstetricians/Gynecologists (1986). Obstetric gynecologic neonatal nursing standards of practice. Washington DC: The Association.

Palmer, J., Jennings, G., \& Massey, L. (1985). Development of an assessment form Attitude toward weight gain during pregnancy. Research, 15(8), 946-949.

Parsons, J. E. (1980). Psychosexual Neutrality: Is anatomy destiny? In J. Parsons (Ed.) The psychology of sex differences and sex roles, (pp. 3-29). New York: McGraw Hill.

The President's Commission of Mental Health (1978). Report to the President from the President's Commission on Mental Health, Vol. 1. Washington, DC: U.S. Government Printing Office.
Renshaw, D.C. (1983). Sex, intimacy, and the older woman. Women and Health, 8(4), 43-55.

Russel, D. (1984). Sexual exploitation, rape, child abuse, and sexual harassment. Beverly Hills: Sage.

Sampselle, C. (in press). Violence against women: Nursing Research, Education, and Practice issues. Washington D.C.: Hemisphere Publishing Corporation.

Scully, D. (1982). Men who control women's health. New York: Random House.

Sontag, S. (1972). The double standard of aging. Saturday Review of the Society, 95(39), 29-38.

Thorne, B., Kramarae, C., \& Henley, N. (1983) . Language, gender, and society. Rowley, MA: Newbury House.

Voda, A., \& George, T. (1986). Menopause. Annual Review of Nursing Research, 4,5575.

West, C., \& Zimmerman, D. (1983). Small insults: A study of interruptions in cross-sex conversations between unacquainted persons. In B. Thorne, C. Kramarae, \& N. Henley (Eds.), Language, gender, and society (pp.102-117). Rowley, MA: Newbury House.

Woods, N. (1982). Menopausal distress: A model for epidemiologic investigation. In A. M. Voda, M. Dinnerstein, \& S. O'Donnell (Eds.), Changing perspectives on menopause (pp. 220-247). Austin: University of Texas Press.

\section{World Class \\ Frances Payne Bolton School of Nursing}

Case Western Reserve University

Joyce J. Fitzpatrick, Ph.D., FAAN

Dean And Professor of Nursing

Programs of Study

-R.N. to M.S.N. $\quad$ M.S.N. $\quad$ Ph.D.

Concentrations

-Administration

-Gerontology

-Anesthesia

-Care of Children

-Medical-Surgical

- Critical Care

-Midwifery

-Community Health

- Nursing Education

-Geriatric Mental Health

-Perinatal

-Psychiatric-Mental Health

You Can Be a Part of This World-Class Facility

For more information call:

1-800-362-8600 ext. 2526 (in Ohio)

1-800-321-6984 ext. 2526 (continental US)

CASE WESTERN RESERVE UNIVERSITY CLEVELAND, OHIO 44106 